\title{
HLA among Brazilian patients with spontaneous chronic urticaria and positive autologous serum skin test
}

\author{
HLA em brasileiros com urticária crônica espontânea e teste cutâneo \\ do soro autólogo positivo
}

\author{
Zamir Calamita ${ }^{1}$ \\ Márcia Gamberini ${ }^{3}$ \\ Odilon Marques de Almeida Filho5 \\ Dione G. Arevalo
}

\author{
Andrea Bronhara Pelá2 \\ Wilson Baleotti Júnior ${ }^{4}$ \\ Marcelo O. Ruiz ${ }^{6}$ \\ Antônio Fabron Júnior ${ }^{8}$
}

\begin{abstract}
BACKGROUND: An association between class I and II alleles of the major histocompatibility complex and idiopathic chronic urticaria has previously been observed in different populations, but there are still no studies on Brazilian populations in this regard.

OBJECTIVE: The involvement of the major histocompatibility complex classes I and II (loci A, B and DR) in Brazilian patients with idiopathic chronic urticaria and a positive autologous serum skin test was investigated and compared with a healthy population group.

MEтноDs: DNA was extracted from the blood of 42 patients with idiopathic chronic urticaria and major histocompatibility complex classes I and II alleles were determined using the polymerase chain reaction and a laboratory test for oligonucleotide hybridization using a single-filament probe. The frequencies of these alleles in patients with chronic urticaria were compared with the frequencies in 1000 genetically unrelated voluntary blood donors from the same region of Brazil. The diagnosis of idiopathic chronic urticaria was based on the patients' clinical history and routine laboratory tests. Only the patients with positive autologous serum skin test were selected. The allele distribution resulted from the patient and control groups were analyzed using odds ratios and $95 \%$ confidence intervals.

RESutTs: No statistically significant differences were found between the positive autologous serum skin test patients with chronic urticaria and the control group.

ConcLusions: We found that in this population group, there was no specific association between the HLA alleles studied and chronic urticaria. We believe that further population studies are needed in order to investigate the possible existence of this association.

Keywords: Genes, MHC class I; Genes, MHC class II; HLA antigens; Skin tests; Urticaria
\end{abstract}

Resumo: FunDAmENTOS: A associação entre os alelos do MHC classe I e II e a urticária crônica idiopática tem sido previamente constatada em diferentes populações, sendo que na população brasileira ainda não existem estudos a este respeito.

OBjETIVos: Foi estudado o envolvimento do MHC classe I e II (locci A, B e DR) em pacientes brasileiros com urticária crônica idiopática e teste cutâneo do soro autólogo positivo, comparando-se com um grupo populacional saudável.

MÉTodos: O DNA foi extraído do sangue de 42 pacientes com urticária crônica idiopática e o MHC classe I e II determinado por reação em cadeia da polimerase e teste laboratorial de hibridização de oligonucleotídeo com sonda de filamento único. A freqüência destes alelos em pacientes com urticária crônica idiopática foi comparada com a de 1000 doadores de sangue voluntários e geneticamente não relacionados, da mesma região do Brasil. O diagnóstico de urticária crônica idiopática foi baseado na história clínica do paciente e exames laboratoriais de rotina; foram selecionados apenas os pacientes com teste cutâneo do soro autólogo positivo. O resultado da distribuição alélica entre o grupo de pacientes e o grupo controle foi analisado através do odds rate com o cálculo do intervalo de confiança de $95 \%$ (95\% IC).

RESULTADOS: Não foram encontradas diferenças com significância estatística entre os pacientes com urticária crônica teste cutâneo do soro autólogo positivos e o grupo controle.

CONCLUSÕES: Verificamos que neste grupo populacional estudado não houve associação específica entre os alelos HLA estudados e a urticária crônica; acreditamos na necessidade de outros estudos populacionais, para podermos verificar a possível existência desta associação. Palavras-chave: Antígenos HLA; Genes Classe I do Complexo de Histocompatibilidade (MHC); Genes Classe II do Complexo de Histocompatibilidade (MHC); Testes Cutâneos; Urticária

Received on 26.05.2011.

Approved by the Advisory Board and accepted for publication on 23.08.2011.

* Work performed at the Faculdade Estadual de Medicina de Marília (FAMEMA) - Marília (SP), Brazil.

Financial Support: None

Conflict of Interests: None

\footnotetext{
PhD - Physician responsible for the Discipline of Allergy and Clinical Immunology of the Faculdade Estadual de Medicina de Marilia (FAMEMA) - Marília (SP), Brazil. Dermatologist - Dermatology Teacher at the Faculdade Estadual de Medicina de Marília (FAMEMA) - Marília (SP), Brazil.

PhD - Pharmacist and Responsible for the Research Sector of the Laboratório de Imunologia de Marília (LIM) - Marília (SP), Brazil.

$\mathrm{PhD}$ - Biomedical and Teacher Responsible for the Immune-Hematology Sector of the Hematology Center of the Faculdade Estadual de Medicina de Marília (FAMEMA) - Marília (SP), Brazil.

PhD - Pharmacist and Immunologist, Chief of the Basic Immunology Discipline of the Faculdade Estadual de Medicina de Marília (FAMEMA) - Marília (SP), Brazil. Biomedical - Coordinator of the Laboratório de Imunologia de Marília (LIM) - Marília (SP), Brazil.

Biomedical - Laboratory Technician at the Laboratório de Imunologia de Marília (LIM) - Marília (SP), Brazil.

PhD - Physician, Teacher of the Discipline of Hematology of the Faculdade Estadual de Medicina de Marília (FAMEMA) and Coordinator of the Hematology Center of the Faculdade Estadual de Medicina de Marília (FAMEMA) - Marília (SP), Brazil.
}

(C)2012 by Anais Brasileiros de Dermatologia

An Bras Dermatol. 2012;87(4):578-83. 


\section{INTRODUCTION}

Urticaria is characterized by the formation of erythematous-papular lesions that are often pruriginous, which occur singly or in groups, and are generally fleeting and sometimes recurrent. It is classified as chronic when the symptoms persist for more than six weeks, and it is often accompanied by angioedema. ${ }^{1}$

Urticaria is said to be idiopathic when no cause can be discovered. It has been proven that around $30 \%$ to $40 \%$ of the cases of idiopathic chronic urticaria are of autoimmune etiology, resulting from the action of class IgG (immunoglobulin $\mathrm{G}$ ) auto-antibodies directed against high-affinity receptors for immunoglobulin E (IgE) of cutaneous mast cells or against IgE binding to mast cells. ${ }^{2 \cdot 6}$ When autoimmune etiology is suspected, a autologous serum skin test (ASST or auto-serum test) can be performed. The sensitivity and specificity of this test for diagnosing autoimmune urticaria are around $70 \%$.

The so-called human leukocyte antigen (HLA) system consists of polymorphic glycoprotein molecules that are expressed on the surface of all nucleated cells (HLA class I) and in the main cells involved in immune response (HLA class II). The genetic locus involved in the expression of HLA molecules is known as the major histocompatibility complex (MHC).

The HLA molecules serve as "self" markers during the maturation of the thymus, which allow the immunological system to recognize antigens that are foreign to the organism, within the context of HLA "self" molecules. This system is directly involved in several aspects of immune-mediated mechanisms, among which the following are worth highlighting: the organism's defensive response to external infectious aggressors, the process of graft rejection, and the triggering of autoimmune diseases.

Many autoimmune diseases are associated with certain alleles of the HLA system. ${ }^{8}$ In relation to chronic urticaria, few studies in the literature have dealt with this question. ${ }^{9-16}$ Therefore, the present study had the aim of identifying a possible association between specific alleles of the HLA system and ASST-positive chronic urticaria, in a Brazilian population group.

\section{METHODS}

This is a controlled cross-sectional analytical study and the determinations of both samples were made intentionally. The study included 42 adult Brazilians with chronic urticaria (28 women and 14 men) who attended the allergy and clinical immunopathology outpatient service of the Marilia School of Medicine and a private clinic. Both institutions are located in Marilia, a city in the southeastern region of Brazil. This study was conducted between 2008 and
2010.

All of the patients had presented with urticaria for more than six weeks and were ASST-positive. Detailed clinical histories were obtained from the patients, with emphasis on the use of any type of medication, characteristics of their diet and presence of other possible associated diseases such as infectious conditions, neoplasia and autoimmune diseases, in particular thyroid disorders.

Patients with previous history of non-hormonal anti-inflammatory drugs or any other type of medication use were only included in this investigation if, after withdrawing the medication for a period of at least 30 days, the urticaria persisted.

The following laboratory tests were requested: hemogram, erythrocyte sedimentation rate (ESR), ALT, AST, creatinine, serological tests for hepatitis B and C, VDRL, urine I, protoparasitological tests (three samples), total IgE, antinuclear factor (ANF), thyroid-stimulating hormone (TSH) and antithyroid antibodies (antimicrosomal and antithyroglobulin antibodies). Patients with a diagnosis of hypothyroidism who were using levothyroxine were included, provided that their condition was clinically and laboratorially compensated. Likewise, ANF-positive patients were included, but only if they did not present other criteria for a possible diagnosis of collagenosis.

Abnormal results from other laboratory tests that may have had to be requested in the light of other complaints with possible etiological relationships with urticaria also served as parameters for determining exclusions. All cases with other clinically or laboratorially suspected etiological factors for urticaria were excluded, such as physical, infectious, parasitic, dietary, drug-related, collagen-related or neoplasmrelated causes, etc.

The prevalence of classes I and II allele profiles (loci A, B and DRB1) among the patients with urticaria was compared with the prevalence among a healthy population sample. The latter was composed of 1,000 individuals who were extracted randomly from a database of possible voluntary bone marrow donors. These individuals lived in the same region as the patients, but without any kinship with them. This control group sample was part of the National Register of Voluntary Bone Marrow Donors (REDOME), which is coordinated by the National Cancer Institute (INCA), a body linked to the Brazilian Ministry of Health. Patient and control group typing by means of the HLA system were performed by the Marília Immunology Laboratory, which is accredited by the Brazilian Ministry of Health.

The genotyping of the HLA system (A, B and DR) was done on peripheral blood, using the PCR- 
SSO molecular biological method (kit from One Lambda Inc), and the flow cytometry method (Labscan 100 apparatus with the SD-Luminex software). The method starts with amplification of exons 2 and 3 for the loci A and B, and exon 3 for the locus DR. After completing this stage, the amplified exons are hybridized by probes and conjugated with beads that have genetic information identical to that of the amplified exon, thereby enabling HLA typing. The beads are labeled with streptavidin conjugated with phycoerythrin, which makes it possible to detect the hybridization (beads) through this labeling. Green laser light identifies whether the hybridization with the bead under analysis has taken place, while red laser light quantifies the intensity of the fluorescence emitted by the reaction, given that each labeled bead emits a different tone of red. The results obtained through Luminex are interpreted using the Labtype software, which analyzes different positive beads in the sample and thus establishes the likely HLA typing.

Among the patients with chronic urticaria, only those with positive ASST results were included (papules of diameter $1.5 \mathrm{~mm}$ greater than in the negative controls), in accordance with previous descriptions. ${ }^{7}$

For the statistical analysis, we calculated odds ratios (OR) with $95 \%$ confidence intervals $(\mathrm{CI})$, which were applied to the results relating to classes I and II HLA alleles among the patients with chronic urticaria and the population-based control group.

All the patients signed a free and informed consent form, and the study was conducted in accordance with the recommendations of the Declaration of Helsinki and after receiving approval from the ethics committee of the Marília School of Medicine.

\section{RESULTS}

Forty-two patients were assessed, among whom 28 (66.6\%) were women. The patients' mean age was 44 years $(S D \pm 12)$, ranging from 19 to 88 years.

The comparative results regarding the prevalence of allele profiles between the patients with chronic urticaria and the general population (control group) are summarized in tables 1, 2 and 3 .

Briefly, through the OR calculations with 95\% $\mathrm{CI}$, it was observed that for the loci evaluated (A, B and DRB1), there were no statistical differences between the patients and the control group (since all the CI included the value 1.0).

\section{DISCUSSION}

Few studies have dealt with possible associations between the antigen expression of the MHC and chronic urticaria. ${ }^{9-16}$ Among Brazilian populations, no studies of this type had been previously conducted.

Although the present study differed in some
Table 1: Frequencies (\%) of HLA-A alleles in the chronic urticaria patients and control population, with statistical analysis: odds ratios (OR) and 95\% confidence intervals $(\mathrm{CI})$

\begin{tabular}{|c|c|c|c|}
\hline HLA A & $\begin{array}{l}\text { Patients } \\
(n=42)\end{array}$ & $\begin{array}{l}\text { Controls } \\
(n=1000)\end{array}$ & OR (CI) \\
\hline$A^{*} 01$ & 9.52 & 9.41 & $1.01(0.48-2.17)$ \\
\hline$A^{*} 02$ & 27.38 & 25.34 & $1.11(0.68-1.84)$ \\
\hline$A * 03$ & 14.28 & 9.17 & $1.66(0.87-3.18)$ \\
\hline$A^{* 11}$ & 9.52 & 5.8 & $1.71(0.79-3.71)$ \\
\hline$A * 23$ & 2.38 & 4.67 & $0.49(0.12-2.07)$ \\
\hline$A * 24$ & 9.52 & 10.22 & $0.93(0.43-1.98)$ \\
\hline$A * 25$ & 1.20 & 1.35 & $0.85(0.11-6.53)$ \\
\hline$A * 26$ & 5.95 & 3.5 & $1.75(0.67-4.58)$ \\
\hline$A * 29$ & 4.76 & 4.4 & $1.09(0.38-3.10)$ \\
\hline$A * 30$ & 2.38 & 5.64 & $0.41(0.10-1.72)$ \\
\hline$A * 31$ & 1.19 & 4.46 & $0.26(0.03-1.88)$ \\
\hline$A * 32$ & 1.67 & 3.36 & $0.34(0.05-2.53)$ \\
\hline$A * 33$ & 2.38 & 3.11 & $0.76(0.18-3.24)$ \\
\hline$A * 68$ & 8.3 & 5.82 & $1.48(0.65-3.35)$ \\
\hline
\end{tabular}

respects from those conducted previously, particularly in that the results did not demonstrate any statistical difference between the patients with chronic urticaria (ASST-positive) and the control group, certain matters deserve to be analyzed.

It is known that there are associations between different autoimmune diseases and certain HLA alleles. ${ }^{8}$ The initial suspicions that autoimmunity was a possible etiological factor for chronic urticaria, which were raised in the first studies through observation of increased frequencies of antithyroid antibodies, were confirmed through the discovery of anti-IgE and antihigh affinity IgE receptor autoantibodies, along with identification of the likely IgG subclasses and the implied stimulation mechanisms for mast cell degranulation. ${ }^{2-6,17,18}$

In the present study, with the aim of coming closer towards diagnosing autoimmune chronic urticaria, we performed the ASST, although we were aware that the accuracy of the ASST for diagnosing autoimmune etiology is limited. For this diagnosis, in vitro methods would also be important, such as stimulation to release histamine or basophil activation tests (induction of CD 63 molecule expression). ${ }^{19,20,21}$ In fact, ASST is considered an in vivo test that only gives assurance of autoreactivity and does not necessarily define autoimmunity, although even so, it may indicate the possibility of activation of mast cells by autoantibodies. ${ }^{22}$

Among the studies on HLA and chronic urticaria carried out previously, ASST was performed in three of them and the test for stimulating histamine release was also performed in one of them. ${ }^{12,15,16}$ 
Table 2: Frequencies (\%) of HLA-B alleles in the chronic urticaria patients and control population, with statistical analysis: odds ratios (OR) and 95\% confidence intervals $(\mathrm{CI})$

\begin{tabular}{|c|c|c|c|}
\hline HLA B & $\begin{array}{l}\text { Patients } \\
(n=42)\end{array}$ & $\begin{array}{l}\text { Controls } \\
(n=1000)\end{array}$ & OR (CI) \\
\hline $\mathrm{B} * 07$ & 7.14 & 6.74 & $1.07(0.45-2.55)$ \\
\hline $\mathrm{B} * 08$ & 2.43 & 5.06 & $1.72(0.38-7.69)$ \\
\hline$B * 14$ & 5.00 & 5.27 & $0.89(0.32-2.53)$ \\
\hline$B * 15$ & 13.09 & 8.94 & $1.54(0.79-3.01)$ \\
\hline$B * 18$ & 2.38 & 5.24 & $0.44(0.11-1.86)$ \\
\hline $\mathrm{B} * 35$ & 15.47 & 12.15 & $1.32(0.71-2.45)$ \\
\hline$B * 37$ & 3.57 & 1.10 & $3.33(0.91-12.18)$ \\
\hline$B * 38$ & 1.20 & 2.12 & $0.56(0.07-4.23)$ \\
\hline$B * 39$ & 1.20 & 3.46 & $0.33(0.04-2.46)$ \\
\hline$B * 40$ & 2.38 & 4.62 & $0.51(0.12-2.12)$ \\
\hline$B * 41$ & 1.20 & 1.20 & $0.99(0.13-7.72)$ \\
\hline$B * 42$ & 1.20 & 1.42 & $0.85(0.11-6.53)$ \\
\hline$B * 44$ & 9.52 & 10.35 & $0.91(0.43-1.93)$ \\
\hline$B * 45$ & 4.76 & 1.69 & $2.89(0.95-8.80)$ \\
\hline$B * 48$ & 2.38 & 0.59 & $4.04(0.80-20.34)$ \\
\hline$B * 49$ & 2.38 & 2.85 & $0.82(0.19-3.48)$ \\
\hline$B * 50$ & 5.95 & 2.25 & $2.69(1.00-7.26)$ \\
\hline$B * 51$ & 13.51 & 8.52 & $1.45(0.72-2.92)$ \\
\hline$B * 52$ & 1.20 & 2.15 & $0.54(0.07-4.02)$ \\
\hline$B * 53$ & 4.76 & 2.40 & $2.03(0.69-6.00)$ \\
\hline$B * 57$ & 1.20 & 2.89 & $0.56(0.07-4.23)$ \\
\hline
\end{tabular}

However, these tests were not performed in other studies. ${ }^{13,14}$

It is known that the genes that encode HLA molecules present great polymorphism and they may vary between different study populations. Therefore, it is important to define the immunogenetic profiles of different populations when comparisons of allele profiles between patients and healthy individuals in a given region are desired. Within this context, Brazil's continental dimensions, important regional differences and highly diversified population (characterized by a high rate of miscegenation between Caucasians, Amerindians and Africans) lead to the expectation of an even greater diversity of HLA alleles. ${ }^{23,24}$ It is also known that the same disease may have different associations that may even contradict the HLA profile (protective or harmful form), depending on the ethnic or geographical group reported. ${ }^{25}$

We saw in the literature that only one study corroborated our findings ${ }^{9}$, i.e. not finding any specific association between the HLA profile and patients with chronic urticaria. The other studies found that patients with chronic urticaria presented associations with specific alleles: HLA DRB1*04; HLA-Bw4 and DQ1; HLA-B44, HLA-DRB1*01 and DRB1*15; and HLA-B44. ${ }^{9,12-16}$ There were even some inverse (protec-
Table 3: Frequencies (\%) of HLA-DR alleles in the chronic urticaria patients and control population, with statistical analysis: odds ratios (OR) and 95\% confidence intervals $(\mathrm{CI})$

\begin{tabular}{llll}
\hline HLA DR & $\begin{array}{l}\text { Patients } \\
(\mathbf{n}=\mathbf{4 2})\end{array}$ & $\begin{array}{l}\text { Controls } \\
(\mathbf{n}=\mathbf{1 0 0 0})\end{array}$ & OR (CI) \\
\hline DRB1*01 & 7.14 & 10.02 & $0.69(0.29-1.63)$ \\
DRB1*03 & 10.71 & 9.88 & $1.09(0.53-2.25)$ \\
DRB1*04 & 13.09 & 12.19 & $1.08(0.56-2.10)$ \\
DRB1*7 & 13.09 & 12.38 & $1.06(0.55-2.06)$ \\
DRB1*8 & 5.95 & 5.56 & $1.07(0.42-2.74)$ \\
DRB1*9 & 2.38 & 1.71 & $1.41(0.32-6.21)$ \\
DRB1*10 & 3.57 & 2.01 & $1.81(0.53-6.24)$ \\
DRB1*11 & 17.85 & 13.29 & $1.42(0.79-2.55)$ \\
DRB1*12 & 3.57 & 1.75 & $2.14(0.61-7.46)$ \\
DRB1*13 & 9.52 & 13.47 & $0.67(0.32-1.43)$ \\
DRB1*14 & 5.95 & 4.07 & $1.48(0.57-3.85)$ \\
DRB1*15 & 4.76 & 9.81 & $0.46(0.17-1.28)$ \\
DRB1*16 & 2.38 & 3.86 & $0.60(0.14-2.53)$ \\
\hline
\end{tabular}

tive) relationships, with HLA-DRB $1 * 15$, HLA-A24 and HLA-A33. ${ }^{12,14,16}$ Comparison between our study and these others allowed us to suspect that the differences in the findings between them were, as discussed earlier, possibly due to the ethnic and regional variations peculiar to each study. In addition to genetic polymorphism, the regional variations encompassed different exposures to a wide variety of environmental factors, which included infectious agents and toxic dietary habits, etc, within each population group studied.

Among the different theories that exist to explain the mechanism through which HLA may correlate with the triggering of urticaria, there is the hypothesis that the great genetic polymorphism of the MHC may predispose towards or cause difficulty regarding the binding of certain antigens (still not established) and their presentation to T lymphocytes ${ }^{8,12}$. Through molecular mimicry, which is one of the mechanisms responsible for triggering autoimmune diseases and is a model that can also be used in the case of autoimmune chronic urticaria, certain environmental agents (such as infectious or toxic agents, etc) may interfere with the antigen recognition mechanism of the immunological system. ${ }^{26}$ This may cause difficulty in differentiating between self and non-self, and it may "confound" the immune response, thereby allowing the production or action of anti-IgE or anti-high affinity IgE receptor autoantibodies. This characteristic may be involved in the variability of the results found by other authors, given that different environmental factors peculiar to each region could theoretically be acting within this context. Moreover, viral and bacterial agents may function as superantigens, thus producing intense nonspecific immune responses that 
could, in a crossed manner, attack the organism's own structure. These infectious agents may even change the HLA expression (certain alleles would have greater propensity for this), thus making it possible for the antigen presentation to be exacerbated. Autoallergens cannot be excluded since recently "autoallergic" IgE antibodies against thyroid peroxidase (TPO) have been implied to play a role in mast cell degranulation and urticaria induction. ${ }^{27}$ Autoallergen mimicry is also a possibility because the extracellular domain of TPO has a similarity of around $45 \%$ with myeloperoxidases from eosinophils and others pathogens including fungi. ${ }^{27}$

The action of $\mathrm{T}$ regulatory cells ( $\mathrm{T}$ reg) in allergic and autoimmune diseases has recently been much studied in relation both to natural $\mathrm{T}$ reg cells, which develop during thymopoiesis, and to adaptive $\mathrm{T}$ reg cells, which are generated on the periphery consequent to a variety of stimuli (under conditions that are said to be tolerogenic). ${ }^{28-30}$ With a tolerogenic mechanism controlled by $\mathrm{T}$ reg cells, an escape of tolerance to the self could occur, since variations in the binding capacity of self antigens to the slot in the MHC may affect the process of $\mathrm{T}$ cell education in the thymus. There could also be a population of $T$ reg cells that would be incapable of recognizing certain self molecules. ${ }^{8}$ This might also correlate with the genetic polymorphism of the HLA. In addition, the suppressive effect of certain cytokines like IL 10 and TGF- $\beta$, along with environmental factors, may act on adaptive $\mathrm{T}$ reg cells and contribute towards triggering allergies in a general manner. This reasoning can be applied to chronic urticaria. ${ }^{28-30}$

It is also worth mentioning that two authors have studied different forms of presentation of urticaria. They found other associations, such as greater prevalence of HLA-BW35 in acute urticaria and HLAB51 in urticaria associated with joint impairment. 9,10

Some caution is required in interpreting the present study due to the inclusion only of patients ASST positive and the exclusion of patients ASST negative. The analysis between these two different groups based in HLA typing could be interesting.

Finally, another matter to be raised is that in the present study we did not evaluate MHC class I anti- gens (locus C), or the DP and DQ alleles (class II), which would be of interest and could be analyzed in future studies.

In this manner, we believe that the great possibility of combinations of variables relating both to the genetic polymorphism of the HLA and to the diversity of regional environmental factors peculiar to the different populations studied could at least partly explain the heterogeneity of the results found so far from these studies.

It is also important to say that, nationally, despite having an excellent review of chronic urticaria, there are no studies correlating the chronic urticaria with HLA, what makes this subject an open field for future research. ${ }^{31}$

\section{CONCLUSIONS}

We therefore conclude that the Brazilian subjects living in this city in the southeastern region of Brazil, who presented with idiopathic chronic urticaria and were ASST-positive, did not have statistically different prevalence of the HLA alleles studied (HLAA, HLA-B and DRB1), in relation to the control group. We believe that further population-based studies are necessary because of the regional differences (ethnic and environmental factors), in order to investigate the possible existence of associations between different HLA alleles and occurrence of idiopathic chronic urticaria. Correlations with ASST-positive findings should also be evaluated, along with other in vitro tests, such as autoantibody investigations (anti-IgE and anti-high affinity IgE receptor) and tests for histamine release and/or basophil activation. Through these, it will become possible to better understand the etiopathogenic mechanisms involved in triggering chronic urticaria, which is likely to make it possible to trace out new lines of research, including within the field of therapeutics.

\section{ACKNOWLEDGEMENTS:}

We thank the biomedicine professional Lopes LB and the librians Stoco MCM, Faria JB and Lima HMC for their contribuitions in carryng out this work. 


\section{REFERENCES}

1. Greaves M. Chronic urticaria. J Allergy Clin Immunol. 2000;105:664-72.

2. Grattan CEH, Wallington TB, Warin RP, Kennedy CTC, Bradfield JW. A serological mediator in chronic idiopathic urticaria: a clinical, immunological and histological evaluation. Br J Dermatol. 1986;114:583-90.

3. Grattan CEH, Francis DM, Hide M, Greaves MW. Detection of circulating histamine releasing autoantibodies with functional properties of anti-lgE in chronic urticaria. Clin Exp Allergy. 1991;21:695-704.

4. Hide M, Francis DM, Grattan CEH, Hakimi J, Kochan JP, Greaves MW. Autoantibodies against the high-affinity $\mathrm{IgE}$ receptor as a cause of histamine release in chronic urticaria. N Engl J Med. 1993;328:1599-604.

5. Kikuchi Y, Kaplan AP. Mechanisms of autoimmune activation of basophils in chronic urticaria. J Allergy Clin Immunol. 2001;107:1056-62.

6. Soundararajan S, Kikuchi Y, Joseph K, Kaplan AP. Functional assessment of pathogenic IgG subclasses in chronic autoimmune urticaria. J Allergy Clin Immunol. 2005;115:815-21.

7. Sabroe RA, Grattan CEH, Francis DM, Barr RM, Kobza Black A, Greaves MW. The autologous serum skin test: a screening test for autoantibodies in chronic idiopathic urticaria. Br J Dermatol. 1999:140:446-52.

8. Gough SCL, Simmonds MJ. The HLA region and autoimmune disease: associations and mechanisms of action. Curr Genomics. 2007;8:453-65.

9. Van Neste D, Bouillenne C. HLA antigens and urticaria. Arch Dermatol Res. 1978; 261:213-5

10. Pasero G, Olivieri I, Gemignani G, Vitali C. Urticária/arthrits syndrome: report of four B51 positive patients. Ann Rheum Dis. 1989;48:508-11.

11. Haas N, Iwen W, Grabbe J, Uchanska-Ziegler B, Czarnetzki BM. MHC class II antigen expression is increased in different forms of urticária. Int Arch Allergy Immunol. 1996;109:177-82.

12. O'Donnell BF, O'Neill CM, Francis DM, Niimi N, Barr RM, Barlow RJ, et al. Human leucocyte antigen class II associations in chronic urticaria. $\mathrm{Br} J$ Dermatol. 1999;140:853-58.

13. Oztas $P$, Onder M, Gonen $\mathrm{S}$, Oztas MO, Soylemezoglu 0 . Is there any relationship between human leucocyte antigen class II and chronic urticaria? (Chronic urticaria and HLA class II). Yonsei Med J. 2004;45:392-5.

14. Aydogan K, Karadogan SK, Akdag I, Tunali S. HLA class I and class II antigens in Turkish patients with chronic ordinary urticaria. Clin Exp Dermatol. 2006;31:424-9.

15. Coban M, Erdem T, Ozdemir S, Pirim I, Atasoy M, Ikbal M. HLA class I and class II genotyping in patients with chronic urticaria. Int Arch Allergy Immunol. 2008;147:135-9.

16. Bozek A, Krajewska J, Filipowska B, Polanska J, Rachowska R, Grzanka A, et al. HLA status in patients with chronic spontaneous urticaria. Int Arch Allergy Immunol. 2010;153:419-23

17. Kaplan AP. Chronic urticaria: pathogenesis and treatment. J Allergy Clin Immunol. 2004:114:465-74.

18. Kaplan AP, Greaves M. Pathogenesis of chronic urticaria. Clin Exp Allergy. 2009;39:777-87.

19. Asero R, Tedeschi A, Lorini M, Salimbeni R, Zanoletti T, Miadonna A. Chronic urticária: novel clinical and serological aspects. Clin Exp Allergy. 2001;31:1105-10.
20. Platzer MH, Grattan CEH, Poulsen LK, Skov PS. Validation of basophil histamine release against the autologous serum skin test and outcome of serum-induced basophil histamine release studies in a large population of chronic urticaria patients. Allergy. 2005;60:1152-56.

21. De Swerdt A, Van Den Keybus C, Kasran A, Cadot P, Neyens K, Coorevits L, et al. Detection of basophil-activating IgG autoantibodies in chronic idiopathic urticaria by induction of CD63. J Allergy Clin Immunol. 2005;116:662-7.

22. Konstantinou GN, Asero R, Maurer M, Sabroe RA, Schimid-Grendelmeier P, Grattan CEH. EAACI/GA2LEN task force consensus report: the autologous serum skin test in urticaria. Allergy. 2009;64:1256-68.

23. Donadi EA, Mauricio da Silva L, Paula Santos CM, Silveira RD, Deghaide NHS, Ferraz AS, et al. Frequência dos antígenos de histocompatibilidade na população normal da região nordeste do Estado de São Paulo Brasil. Medicina (Ribeirão Preto). 2000;33:19-26.

24. Rosales T, Guilherme L, Chiarella J, Marin ML, Rosales C, Melo CP, et al. Human leukocyte $A$ and $B$ antigen, gene and haplotype frequencies in the population of the city of Sâo Paulo in Brazil. Braz J Med Biol Res. 1992;25:39-47.

25. Wang JH, Zheng X, Ke X, Dorak MT, Shen J, Boodram B, et al. Ethnic and geographical differences in HLA associations with the outcome of hepatitis $\mathrm{C}$ virus infection. Virol J [Internet]. 2009 [cited 2010 Jul 12];6:46. Available from: http://www.virolojyj.com/content/6/1/46

26. Behar SM, Porcelli SA. Mechanisms of autoimmune disease induction: the role of immune response to microbial pathogens. Arthritis Rheum. 1995;38:458-76.

27. Altrichter S, Peter H-J, Pisarevskaja D, Metz M, Martus P, Maurer M. IgE mediated autoallergy against thyroid peroxidase - a novel pathomechanism of chronic spontaneous urticaria. PLoS One. 2011;6:e14794.

28. Romagnani S. Regulatory T cells: which role in pathogenesis and treatment of allergic disorders? Allergy. 2006;61:3-14

29. Kwon HK, Lee CG, So JS, Chae CS, Hwang JS, Sahoo A, et al. Generation of regulatory dendritic cells and CD4+Foxp3 + T cells by probiotics administration suppresses immune disorders. Proc Nati Acad Sci USA. 2010;107:2159-64.

30. Hansen W, Westendorf AM, Buer J. Regulatory T cells as targets for immunotherapy of autoimmunity and inflammation. Inflamm Allergy Drug Targets. 2008;7:217-23.

31. Criado PR, Criado RFJ, Maruta CW, Martins JEC, Rivitti EA. Urticária. An Bras Dermatol. 2005;80:613-30.
MAILING ADDRESS:

Zamir Calamita

Av. Monte Carmelo, 800 - Bairro Fragata

17519-030 Marília, SP

E-mail: calamita@unimedmarilia.com.br

How to cite this article: Calamita Z, Pelá AB, Gamberini M, Baleotti Jr W, Almeida Filho OM, Ruiz MO, Arevalo DG, Fabron Jr A. HLA among brazilian patients with chronic spontaneous urticaria and positive autologous serum skin test. An Bras Dermatol. 2012;87(4):578-83. 